\title{
Fingerprinting polychlorinated biphenyls (PCBs) in environmental samples using comprehensive two-dimensional gas chromatography with time-of- flight mass spectrometry
}

David Megson ${ }^{\mathrm{a}^{*}}$, Robert Kalin ${ }^{\mathrm{b}}$, Paul J. Worsfold ${ }^{\mathrm{a}}$, Caroline Gauchotte-Lindsay ${ }^{\mathrm{c}}$, Donald G. Patterson Jr ${ }^{d}$, Maeve C. Lohan ${ }^{\text {a }}$, Sean Comber ${ }^{a}$, Thomas A. Brown ${ }^{\text {a }}$, Gwen O’Sullivan ${ }^{\text {e }}$

${ }^{a}$ Biogeochemistry Research Centre, SoGEES, Plymouth University, Plymouth, Devon, PL4 8AA, UK

${ }^{\mathrm{b}}$ Department of Civil and Environmental Engineering, University of Strathclyde, Glasgow G1 1XQ, UK

${ }^{c}$ Division of Infrastructure and Environment, School of Engineering, University of Glasgow, Glasgow, G12 8LT, UK

d Exponent Inc., One Capital City Plaza, Suite 1620, 3350 Peachtree Road, Atlanta, GA 30326, USA

e Department of Environmental Science, Mount Royal University, 4825 Mount Royal Gate SW, Calgary, Alberta, T3E 6K6, Canada

\begin{abstract}
A GCxGC-TOFMS installed with a Rtx-PCB $(60 \mathrm{~m} \times 0.18 \mathrm{~mm} \times 0.18 \mu \mathrm{m})$ in the first dimension and Rxi-17 (1.5 $\mathrm{m} \times 0.1 \mathrm{~mm} \times 0.1 \mu \mathrm{m})$ column in the second dimension was used to separate 188 out of 209 congeners. A further 12 congeners were identified through additional data processing resulting in the identification of a total of 200 congeners. However, caution is advised if these 12 congeners were to be used in quantitative assessments. The remaining 9 coeluting congeners were three doublets (CB65 + CB62, CB160 + CB163 and CB201 + CB204) and one triplet $(\mathrm{CB} 20+\mathrm{CB} 21+\mathrm{CB} 33)$. This method was tested on five Aroclors and resulted in the separation of all congeners present in the heavier Aroclor mixtures A1254 and A1260. The suitability of this method for applications in biological matrices was demonstrated on extracted whiting and guillemot liver samples which resulted in the identification of 137 individual PCBs in the whiting liver sample and 120 in the guillemot sample. Fingerprinting was able to show clear differences in the PCB signature of the two animals. This highlights the potential of this method for PCB fingerprinting in environmental forensics studies and other assessments that require congener specific analysis.
\end{abstract}

\section{Key words}

Polychlorinated biphenyls, Comprehensive two-dimensional gas chromatography, Time of flight mass spectrometry, Aroclor

\section{Highlights}

188 out of 209 PCBs separated for quantitation in one analytical run 
200 out of 209 PCBs identified in one analytical run

All PCBs separated in Aroclors A1254 and A1260

137 individual congeners identified in a whiting liver sample

The results highlight the potential of this method for PCB fingerprinting

\section{Introduction}

Polychlorinated biphenyls (PCBs) were first discovered in environmental samples in 1966 [1,2]. However, due to their structural similarity, the separation of all 209 PCBs still presents a significant analytical challenge. In order to achieve positive identification and accurate quantification, all target compounds must be sufficiently resolved. In toxicological studies it is important to separate the World Health Organisation 12 dioxin like PCBs (WHO12) [3]. However, in environmental forensics studies a greater number of congeners often need to be separated to identify processes such as microbial degradation [4], volatilisation [5] and biotransformation in humans [6]. Having the ability to separate and identify specific PCB congeners is essential in environmental studies that require PCB fingerprinting.

Early analytical techniques such as EPA methods 8082 and 608 focused on calculating total PCB concentrations as spills to the environment occurred from technical mixtures such as Aroclors rather than from individual congeners. As more was understood about PCBs it became ever more important to identify and quantify individual PCB congeners. In 1997 Frame [7] documented the retention times and elution orders of all 209 congeners on 20 GC columns which significantly improved the ability of analytical chemists to confidently identify and quantify PCBs in an unknown sample. However, no single GC column is currently able to separate all 209 congeners and so it was necessary to manage datasets with co-elutions or analyse samples on multiple GC columns. The development of comprehensive twodimensional gas chromatography can significantly increase peak capacity and therefore potentially remove the need to undertake repeat sample injections on multiple GC columns [8]. The demand for congener specific analysis lead to the development of EPA method 1668c which states that over 180 individual congeners can be separated using a dual column system.

Recently PCB analysis using GCxGC-TOFMS has been used to separate more than 190 individual PCB congeners along with simultaneous identification of other organohalogenated contaminants [9,10]. Separation of 198 PCBs was undertaken by Harju et al. [11] in 2003 using GC x GC- $\mu$ ECD equipped with a $60 \mathrm{~m}$ DB-XLB in the first dimension $\left({ }^{1} \mathrm{D}\right)$ and $2.25 \mathrm{~m} \mathrm{BPX}-$ 70 in the second dimension $\left({ }^{2} \mathrm{D}\right)$. This resulted in co-elutions of one triplet and four doublets. No co-elutions were recorded for either the 12 'dioxin like' congeners (WHO12) or European indicator PCBs (EC7), in addition the run time was up to 4 hours long. Separation of 194 congeners was reported by Focant et al. [12] in 2004 using GCxGC-TOFMS equipped with a $60 \mathrm{~m}$ DB-XLB in ${ }^{1} \mathrm{D}$ and $2.5 \mathrm{~m}$ BPX-50 in ${ }^{2} \mathrm{D}$; However this resulted in co-elutions of one triplet and six doublets. One co-elution was recorded for a WHO12 congener (CB123) and two co-elutions were recorded for the EC7 congeners (CB101 and CB153). Separation of 196 
congeners was reported by Zapadlo et al. [13] in 2011 using GC x GC-TOFMS equipped with a $30 \mathrm{~m}$ SPB-Octyl in ${ }^{1} \mathrm{D}$ and $1.8 \mathrm{~m}$ SLB-IL59 in ${ }^{2} \mathrm{D}$. However this resulted in co-elutions of one triplet and five doublets. No co-elutions were recorded for the WHO12 congeners and two co-elutions were recorded for the EC7 congeners (CB101 and CB153).

GCxGC-TOFMS has therefore been shown to be a powerful technique for resolving PCB congeners. Several papers have been published on PCB separation using a variety of column combinations [9-13]; however none of these studies investigated the use of the recently developed Rtx-PCB column (commercially available since 2005). This paper reports the separation achieved using a PCB specific low polarity column in ${ }^{1} \mathrm{D}$ with a stationary phase which is predominantly dimethylpolysiloxane (Rtx-PCB), coupled with a mid-polarity column in ${ }^{2} \mathrm{D}$ with a stationary phase which is $50 \%$ diphenyl, $50 \%$ dimethyl polysiloxane (Rxi-17). This method was tested on the five most common Aroclor solutions [14] and its application to biological matrices was demonstrated through analysis of extracted liver samples taken from a whiting obtained from the English Channel and a guillemot recovered from the coast of Great Britain.

\section{Materials and methods}

\subsection{Chemicals, standards and samples}

Individual $\mathrm{PCB}$ congeners were identified using nine $\mathrm{PCB}$ congener standard calibration mixtures (CS1 to CS9; AccuStandard) containing $10 \mu \mathrm{g} \mathrm{mL}^{-1}$ of each PCB in $1 \mathrm{~mL}$ of isooctane. Approximately $50 \mu \mathrm{L}$ of CS1 - CS9 were combined to produce a solution containing all 209 congeners (209 PCB solution). Five certified PCB technical mixtures (99\% purity) were obtained at a concentration of $1000 \mu \mathrm{g} \mathrm{mL}^{-1}$ including; Aroclor 1016, Aroclor 1254 and Aroclor 1260 (Fisher Chemicals), Aroclor 1242 and Aroclor 1248 (Greyhound Chromatography). Prior to analysis, all Aroclors were made up to concentrations of $10 \mathrm{mg} \mathrm{L}^{-1}$ through serial dilution with hexane (for dioxins, furans and PCBs; Sigma-Aldrich). One whiting and one guillemot liver sample were prepared using established techniques for extraction of organic biomarkers in marine tissue reported by Brown et al. [15]. Briefly this involved; freeze drying and grinding samples into a powder before sonication and extraction with dichloromethane/methanol. Extracts were filtered, dried and re-suspended in hexane and the non-polar fraction separated by column chromatography $\left(\mathrm{SiO}_{2}\right)$. Samples were evaporated to dryness and reconstituted with $10 \mu \mathrm{L}$ of hexane prior to analysis.

\subsection{GCXGC-TOFMS analysis and data processing}

Samples were analysed on a time-of-flight mass spectrometer, (Leco, St. Joseph, MI Pegasus 4D) coupled to a two dimensional gas chromatograph (Agilent Technologies 7890A) equipped with a thermal modulator (Leco, St. Joseph, MI). The gas chromatograph was installed with a Rtx-PCB (60 m x $0.18 \mathrm{~mm} \times 0.18 \mu \mathrm{m}){ }^{1} \mathrm{D}$ column and a Rxi-17 $(1.5 \mathrm{~m} \times 0.1 \mathrm{~mm} \times 0.1 \mu \mathrm{m}){ }^{2} \mathrm{D}$ column. One $\mu \mathrm{L}$ of sample was injected in splitless mode, analytical blanks were run with each batch of up to 10 samples and the same 209 PCB mix solution was analysed in triplicate. 
The GC inlet temperature was set at $280{ }^{\circ} \mathrm{C}$ with a helium carrier gas flow rate of $1 \mathrm{~mL} \mathrm{~min}{ }^{-1}$ and a purge time of $120 \mathrm{~s}$ at a flow rate of $20 \mathrm{~mL} \mathrm{~min}^{-1}$. The primary oven temperature was initially set at $90{ }^{\circ} \mathrm{C}$ for $1 \mathrm{~min}$, then increased to $150{ }^{\circ} \mathrm{C}$ at $30{ }^{\circ} \mathrm{C} \mathrm{min}{ }^{-1}$, then to $300{ }^{\circ} \mathrm{C}$ at $1{ }^{\circ} \mathrm{C}$ $\min ^{-1}$. The secondary oven temperature was set at $20{ }^{\circ} \mathrm{C}$ higher than the primary oven temperature. The modulator temperature was also set at $20{ }^{\circ} \mathrm{C}$ higher than the primary oven temperature, the modulation period was $3 \mathrm{~s}$ with a hot-pulse duration of $700 \mathrm{~ms}$ and the cooling time was $800 \mathrm{~ms}$. The transfer line and detector temperature was set at $300{ }^{\circ} \mathrm{C}$. The mass spectrometer was operated with a source ionisation energy of $70 \mathrm{eV}$, detector voltage of 1800 $\mathrm{V}$ and the data acquisition rate of 100 spectra s$^{-1}$ for $100-550$ Daltons.

The run time for each sample was $153 \mathrm{~min}$. All data files were processed using ChromaTOF software. The processing method was set to identify 10,000 peaks with a signal-to-noise ratio of greater than 10:1. Throughout this paper PCBs are referred to using the Guitart et al. [16]numbering system.

\subsection{Quality control procedures}

Analytical blanks were run with each batch of approximately 10 samples. All samples were spiked with a ${ }^{13} \mathrm{C}_{12}$ internal standard. Standard mixtures were analysed in triplicate to check that separation was consistently achieved. Standard solutions in decreasing concentrations were analysed to establish the limit of detection for individual congeners; the lowest concentration of an individual congener that could be consistently detected was $1 \mathrm{pg} \mu \mathrm{L}^{-1}$.

\section{Results and discussion}

\subsection{Identification of all 209 congeners}

Calibration solutions CS1 to CS9 were run individually and retention times were compared with literature values on elution order produced by Leco Corporation [17] to identify each congener. Figure 1 shows the two-dimensional retention times for all 209 PCB congeners, grouped by their degree of chlorination.

$<<$ Figure 1 $>>$ Plotted peak apexes representing the two-dimensional retention times for all 209 PCB congeners

Analysis of the 209 PCB solution resulted in the separation of 188 individual PCBs with nine doublets and one triplet that could not be resolved by comprehensive two dimensional chromatography with mass spectrometric detection. Co-eluting PCBs were investigated to see if they could be identified by further data interpretation. This included comparing slices of the one dimensional chromatogram as well as spectral deconvolution which was undertaken using the ChromaTOF software. The results of which are presented in the supplementary material. Using further data interpretation, six of the co-eluting doublets were identified in all three triplicate samples (CB4 + CB10, CB67 + CB58, CB95 + CB88, CB84 + CB89, CB101 + CB90 and CB175 + CB182). This resulted in the identification of a total of 200 of the 209 PCBs in the mixture (Table 1). Although the separation was sufficient to allow for each congener to be visually identified, quantification of these congeners would need to be undertaken using further data analysis. There were no isobaric overlaps between PCBs and fragments of higher 
homologues $-2 \mathrm{Cl}$ (e.g. hexa-CB fragment $-2 \mathrm{Cl}$ and tetra- $\mathrm{CB}$ ). However, there were several coelutions within higher homologous series $-1 \mathrm{Cl}$ (e.g. hexa-CB fragment $-1 \mathrm{Cl}$ and penta-CB). These should also be considered when undertaking quantitative analysis.

$<<$ Table $1>>$ Elution order and retention times of all 209 congeners

When including the congeners that were resolved by further data interpretation, no co-elutions were recorded that involved either the WHO12 or EC7 congeners. Figure 2 presents the nine co-eluting doublets and one triplet that could not be separated by comprehensive twodimensional chromatography, along with their percentage abundances in the five major Aroclors [18].

$<<$ Figure 2 $>>$ Summary of congeners that could not be resolved by chromatography are presented as contour plots along with their documented retention times and percentage abundance in the five main Aroclors.

The co-elutions from this study are presented in Table 2 along with co-elutions for various column combinations reported by other authors. This is intended to help future researchers decide on the column combination that would best suit their needs.

$<<$ Table $2>>$

\subsection{Identification of PCBs in 5 Aroclors}

PCBs were produced as commercial mixtures such as Aroclors. During the manufacturing process there are several congeners that do not have favourable chlorine substitution patterns, such as PCBs with one heavily chlorinated biphenyl and one un-chlorinated biphenyl [18]. These PCBs are therefore unlikely to be present in detectable concentrations in environmental and animal tissue samples. Analysis of the five most common Aroclors (A1016, A1242, A1248, A1254 and A1260) was undertaken to identify co-elutions in these commercial mixtures. Results were compared with the database of PCBs in Aroclors compiled by Frame [18] which was based on data from Frame et al. [19]. All PCBs present in the heavier Aroclor mixtures A1254 and A1260 were identified, along with 113 of the 115 congeners in A1248 (co-elutions of CB88 + CB95), 96 of the 99 congeners in A1242 (co-elutions of CB20 + CB21 + CB33) and 63 of the 66 congeners in A1016 (co-elutions of CB20 + CB21 + CB33).

As with the 209 PCB solution, this method was unable to separate CB33 + CB20 + CB21 in any Aroclor. However, the sample of A1248 did not contain detectable concentrations of CB20 which allowed CB33 to be resolved from CB21.

\subsection{Identification of PCBs in animal tissue sample}

The application of this method to biological matrices was demonstrated through analysis of extracted liver samples taken from a whiting and guillemot. These samples were used as an example of the complex matrices that are often experienced in environmental forensics investigations. This method identified 137 individual PCBs in the whiting liver, with a further 
18 tentatively identified with a signal-to-noise ratio $<10$. This method also identified 120 PCBs in the guillemot liver with a further 11 tentatively identified with a signal-to-noise ratio $<10$. The same 112 PCBs were positively identified in both samples. The relative proportions of the peak areas of these 112 congeners clearly showed a different PCB signature in each animal (Figure 3). This highlights the potential of this method for PCB fingerprinting in environmental forensics studies.

$<<$ Figure $3>>$ PCB signature in whiting and Guillemot liver. One hundred and twelve PCBs were resolved by GCxGC-TOFMS in both samples. PCBs are arranged by elution order on the first dimension column (Rtx-PCB $60 \mathrm{~m} \times 0.18 \mathrm{~mm} \times 0.18 \mu \mathrm{m}$ )

Several other persistent organic pollutants (POPs) were also identified in the same tissue samples by library matching against the NIST database, including DDE, chlordane, hexachlorobenzene, Mirex ${ }^{\circledR}$, nonachlor and heptaclor isomers, indicating that this method could also be used as a broader screening tool. p'p'-DDE co-eluted with CB154, but these compounds could be distinguished by their different mass spectra. In both samples, a peak was detected for the co-elutions of CB20 + CB21 + CB33, CB88 + CB95, CB89 + CB84, CB90 + $\mathrm{CB} 101, \mathrm{CB} 182+\mathrm{CB} 175$ and CB201 + CB204. Spectral deconvolution was able to separate $\mathrm{CB} 20+\mathrm{CB} 33, \mathrm{CB} 89+\mathrm{CB} 84, \mathrm{CB} 90+\mathrm{CB} 101$, and $\mathrm{CB} 182+\mathrm{CB} 175$ in the whiting liver and $\mathrm{CB} 89+\mathrm{CB} 84, \mathrm{CB} 90+\mathrm{CB} 101$ and CB182 + CB175 in the guillemot liver. CB163 could not be consistently resolved from $\mathrm{CB} 160$ in the 209 PCB mix analysed in triplicate. However, CB160 did not appear to be present at detectable concentrations $\left(1 \mathrm{pg} \mu \mathrm{L}^{-1}\right)$ in the biological samples and therefore the peak was recorded as CB163.

The ability of spectral deconvolution to separate co-eluting congeners varied between the different samples and therefore caution is advised when undertaking quantitative analysis of these congeners as it may be better to report them as co-eluting congeners. The spectra for congeners from the same level of chlorination are very similar; however it has been shown that by using a combination of retention time and ion ratio information it is possible to confidently identify individual congeners [17].

\section{Conclusions}

One hundred and eighty eight of the 209 PCB congeners were separated using a Leco Pegasus 4D GCxGC-TOFMS installed with a Rtx-PCB $(60 \mathrm{~m} \times 0.18 \mathrm{~mm} \times 0.18 \mu \mathrm{m})$ in the first dimension and Rxi-17 (1.5 $\mathrm{m} \times 0.1 \mathrm{~mm} \times 0.1 \mu \mathrm{m})$ in the second dimension A further 12 congeners were identified through additional data processing, resulting in the identification of a total of 200 congeners. However, caution is advised if these 12 congener are used for quantitative assessments. The only congeners that could not be resolved were $\mathrm{CB} 30+\mathrm{CB} 20+$ CB21, CB65 + CB62, CB160 + CB163, CB201 + CB204. This method was tested on five Aroclors and its suitability for application to biological matrices was demonstrated on extracted whiting and guillemot liver samples. All PCBs present in the heavier Aroclor mixtures A1254 and A1260 were separated. One hundred and thirty seven individual PCBs were positively identified in a whiting liver sample which had a distinctly different signature when compared with a guillemot liver sample. This highlights the potential of this method for PCB fingerprinting in environmental forensics studies. 


\section{Acknowledgments}

The authors would like to thank; Chris Gallagher and Ann Tanderitispole (University of Strathclyde) for their assistance and hard work running the samples and standards, Christopher Hopley (LGC) for kindly donating the nine native congener mix solutions 209 PCB solutions, Russell Haworth (Thames Restek), Jack Cochran (Restek) and Alec Kettle (Leco) for their useful advice and support with the project. The Scottish Funding Council and EPSRC Grant GR/T25200/01 for funding associated with the University of Strathclyde Laboratory. Finally David Megson would like to thank Plymouth University for funding this project as part of his $\mathrm{PhD}$ research.

\section{References}

[1] The International Programme on Chemical Safety (IPCS), Environmental Health Criteria 140, Polychlorinated Biphenyls and Terphenyls, World Health Organisation, Geneva, 1993.

[2] S. Jensen, New Scientist 32 (1966) 612.

[3] M. van den Berg, L.S. Birnbaum, M. Denison, M. De Vito, W. Farland, M. Feeley, H. Fiedler, H. Hakansson, A. Hanberg, L. Haws, M. Rose, S. Safe, D. Schrenk, C. Tohyama, A. Tritscher, J. Tuomisto, M. Tysklind, N. Walker, R.E. Peterson, Toxicological Sciences 223241 (2006) 93.

[4] D.L. Bedard, J.F. Quensen III, in L.Y. Young, C. Cerniglia (Editors), Microbial Transformationand Degradation of Toxic Organic Chemicals, Wiley-Liss Division, Wiley \& Sons, Inc, New York, 1995.

[5] J.R. Chiarenzelli, R.J. Scrudato, M.L. Wunderlich, Environmental Science \& Technology 31 (1997) 597.

[6] D. Megson, G. O’Sullivan, S. Comber, P.J. Worsfold, M.C. Lohan, M.R. Edwards, W.J. Shields, C.D. Sandau, D.G. Patterson Jr, Science of the Total Environment 461-462 (2013) 99.

[7] G.M. Frame, Fresenius Journal of Analytical Chemistry 357 (1997) 701.

[8] E.J. Reiner, K.L. Jobst, D. Megson, F.L. Dorman, J.F. Focant, in G. O'Sullivan, C.D. Sandau (Editors), Environmental Forensics for Persistent Organic Pollutants, Elsevier, in press.

[9] J.F. Focant, A. Sjodin, W.E. Turner, D.G. Patterson Jr, Analytical Chemistry 76 (2004) 6313.

[10] P. Korytar, P. Haglund, J. de Boer, U.A.T. Brinkman, Trac-Trends in Analytical Chemistry 25 (2006) 373. 
[11] M. Harju, C. Danielsson, P. Haglund, Journal of Chromatography A 1019 (2003) 111.

[12] J.F. Focant, A. Sjodin, D.G. Patterson Jr, Journal of Chromatography A 1040 (2004) 227

[13] M. Zapadlo, J. Krupcik, T. Kovalczuk, P. Majek, I. Spanik, D.W. Armstrong, P. Sandra, Journal of Chromatography A 1218 (2011) 746.

[14] R.L. Durfree, G. Contos, F.C. Whitmore, J.D. Barden, E.E.I. Hackman, R.A. Westin, (1976). US EPA publication no. 560/6-76-005:88

[15] T.A. Brown, S.T. Belt, S.H. Ferguson, D.J. Yurkowski, N.J. Davison, J.E.F. Barnett, P.D. Jepson, Journal of Experimental Marine Biology and Ecology 441 (2013) 99.

[16] R. Guitart, P. Puig, J. Gomez-Catalan, Chemosphere 27 (1993) 1451.

[17] Leco Corporation, (2011) Form No. 203-821-380.

[18] G.M. Frame, in L.W. Robertson, L.G. Hansen (Editors), PCBs Recent Advances in Environmental Toxicology and Health Effects, The University Press of Kentucky, 2001,

[19] G.M. Frame, J.W. Cochran, S.S. Bowadt, Hrc-Journal of High Resolution Chromatography 19 (1996) 657. 


\section{Tables}

Table 1. Elution order and retention times of all 209 congeners recorded using a Leco Pegasus 4D GCxGC-TOFMS equipped with a $60 \mathrm{~m}$ Rtx-PCB and $1.5 \mathrm{~m}$ Rxi-MS. Congeners in bold are present at $>1 \%$ in the five main Aroclors, congeners in italics are present at $<0.01 \%$ in the five main Aroclors. WHO12 congeners are marked with ${ }^{*}$, EC7 congeners are marked with ${ }^{+}$

\section{Represents co-eluting congeners \\ Represents congeners separated by further processing}

\begin{tabular}{|c|c|c|c|c|c|c|c|}
\hline РCB & $\begin{array}{l}\text { Chlorine } \\
\text { position }\end{array}$ & $\begin{array}{c}{ }^{1} \mathrm{D} \\
\text { Retention } \\
\text { Time (min) }\end{array}$ & $\begin{array}{c}{ }^{2} \mathrm{D} \\
\text { Retention } \\
\text { Time (s) } \\
\end{array}$ & РСВ & $\begin{array}{l}\text { Chlorine } \\
\text { position }\end{array}$ & $\begin{array}{c}{ }^{1} \mathrm{D} \\
\text { Retention } \\
\text { Time (min) }\end{array}$ & $\begin{array}{c}{ }^{2} \mathrm{D} \\
\text { Retention } \\
\text { Time (s) } \\
\end{array}$ \\
\hline \multicolumn{4}{|c|}{ Mono-chlorobiphenyls } & \multicolumn{4}{|c|}{ Penta-chlorobiphenyls cont. } \\
\hline 1 & 2 & 28.35 & 1.64 & 120 & $245-3^{\prime} 5^{\prime}$ & 87.1 & 2.12 \\
\hline 2 & 3 & 34.75 & 1.67 & 97 & 245-2'3' & 87.45 & 2.22 \\
\hline 3 & 4 & 36.2 & 1.67 & 116 & 23456 & 88.5 & 2.22 \\
\hline \multicolumn{4}{|c|}{ Di-chlorobiphenyls } & 87 & 234-2'5' & 89.3 & 2.21 \\
\hline 4 & $2-2$ & 37.45 & 1.91 & 111 & $235-3^{\prime} 5^{\prime}$ & 89.8 & 1.89 \\
\hline 10 & 26 & 37.55 & 1.87 & 117 & $2356-4^{\prime}$ & 89.85 & 2.14 \\
\hline 9 & 25 & 42.35 & 1.81 & 115 & $2346-4^{\prime}$ & 90.05 & 2.16 \\
\hline 7 & 24 & 42.65 & 1.79 & 85 & $234-2^{\prime} 4^{\prime}$ & 90.25 & 2.23 \\
\hline 6 & $2-3^{\prime}$ & 43.9 & 1.88 & 109 & $235-3^{\prime} 4^{\prime}$ & 90.95 & 1.92 \\
\hline 5 & 23 & 45.2 & 1.95 & 110 & $236-3^{\prime} 4^{\prime}$ & 91.15 & 2.22 \\
\hline 8 & $2-4^{\prime}$ & 45.7 & 1.88 & 82 & $234-2^{\prime} 3^{\prime}$ & 92.9 & 2.38 \\
\hline 14 & 35 & 48.55 & 1.75 & 124 & $345-2^{\prime} 5^{\prime}$ & 95.25 & 2.05 \\
\hline 11 & $3-3^{\prime}$ & 52.55 & 1.84 & 108 & $2346-3^{\prime}$ & 95.95 & 2.08 \\
\hline 12 & 34 & 53.65 & 1.89 & $123^{*}$ & $345-2^{\prime} 4^{\prime}$ & 96.15 & 2.11 \\
\hline 13 & $3-4^{\prime}$ & 54.6 & 1.85 & 107 & $234-3^{\prime} 5^{\prime}$ & 96.3 & 2.07 \\
\hline 15 & $4-4$ & 56.75 & 1.85 & 106 & $2345-3^{\prime}$ & 96.55 & 2.12 \\
\hline \multicolumn{4}{|c|}{ Tri-chlorobiphenyls } & $118^{*+}$ & $245-3^{\prime} 4^{\prime}$ & 97.3 & 2.08 \\
\hline 19 & $26-2^{\prime}$ & 48 & 2.12 & 122 & $345-23^{\prime}$ & 98.45 & 2.24 \\
\hline 30 & 246 & 49.75 & 1.88 & $114^{*}$ & $2345-4^{\prime}$ & 99.25 & 2.17 \\
\hline 18 & 25-2' & 52.2 & 2.01 & $105^{\star}$ & 234-3'4' & 102.3 & 2.25 \\
\hline 17 & 24-2' & 52.8 & 1.99 & 127 & $345-3^{\prime} 5^{\prime}$ & 103.45 & 1.92 \\
\hline 27 & $26-3^{\prime}$ & 53.9 & 2.05 & $126^{*}$ & $345-3^{\prime} 4^{\prime}$ & 109.65 & 2.1 \\
\hline 24 & 236 & 54.6 & 2.04 & \multicolumn{4}{|c|}{ Hexa-chlorobiphenyls } \\
\hline 16 & 23-2' & 55.6 & 2.16 & 155 & $246-2^{\prime} 4^{\prime} 6^{\prime}$ & 80.35 & 2.11 \\
\hline 32 & $26-4^{\prime}$ & 56.25 & 2.05 & 150 & $236-2^{\prime} 4^{\prime} 6^{\prime}$ & 84.95 & 2.25 \\
\hline 34 & $35-2^{\prime}$ & 57.55 & 1.91 & 152 & $2356-2^{\prime} 6^{\prime}$ & 85.9 & 2.35 \\
\hline 23 & 235 & 58 & 1.92 & 145 & $2346-2^{\prime} 6^{\prime}$ & 87.15 & 2.36 \\
\hline 29 & 245 & 58.65 & 1.94 & 148 & $235-2^{\prime} 4^{\prime} 6^{\prime}$ & 88 & 2.09 \\
\hline 26 & $25-3^{\prime}$ & 60.3 & 1.92 & 154 & $245-2^{\prime} 4^{\prime} 6^{\prime}$ & 89.5 & 2.11 \\
\hline 25 & $24-3^{\prime}$ & 60.85 & 1.94 & 136 & $236-2^{\prime} 3^{\prime} 6^{\prime}$ & 89.6 & 2.38 \\
\hline 31 & $25-4^{\prime}$ & 62.55 & 1.93 & 151 & 2356-2'5' & 92.35 & 2.17 \\
\hline $28^{+}$ & 24-4' & 63.1 & 1.94 & 135 & $235-2^{\prime} 3^{\prime} 6^{\prime}$ & 92.7 & 2.22 \\
\hline 33 & 34-2' & 63.3 & 2.06 & 144 & $2346-2^{\prime} 5^{\prime}$ & 93.25 & 2.18 \\
\hline 21 & 234 & 63.35 & 2.09 & 147 & $2356-2^{\prime} 4^{\prime}$ & 94.05 & 2.21 \\
\hline 20 & 23-3' & 63.5 & 2.08 & 149 & $236-2^{\prime} 4^{\prime} 5^{\prime}$ & 94.15 & 2.25 \\
\hline 22 & 23-4' & 65.75 & 2.09 & 143 & $2345-2^{\prime} 6^{\prime}$ & 94.6 & 2.37 \\
\hline 36 & $35-3^{\prime}$ & 67.5 & 1.82 & 139 & $2346-2^{\prime} 4^{\prime}$ & 94.75 & 2.22 \\
\hline 39 & $35-4^{\prime}$ & 69.95 & 1.86 & 140 & $234-2^{\prime} 4^{\prime} 6^{\prime}$ & 95.2 & 2.25 \\
\hline 38 & 345 & 70.15 & 1.98 & 134 & 2356-2'3' & 96.4 & 2.32 \\
\hline 35 & $34-3^{\prime}$ & 73.25 & 1.98 & 142 & $23456-2^{\prime}$ & 96.7 & 2.36 \\
\hline 37 & $34-4^{\prime}$ & 75.75 & 1.99 & 133 & 235-2'3'5' & 97 & 2.06 \\
\hline \multicolumn{4}{|c|}{ Tetra-chlorobiphenyls } & 131 & 2346-2'3' & 97.15 & 2.35 \\
\hline
\end{tabular}




\begin{tabular}{|c|c|c|c|c|c|c|c|}
\hline РСB & $\begin{array}{l}\text { Chlorine } \\
\text { position }\end{array}$ & $\begin{array}{c}{ }^{1} \mathrm{D} \\
\text { Retention } \\
\text { Time (min) }\end{array}$ & $\begin{array}{c}{ }^{2 D} \\
\text { Retention } \\
\text { Time (s) } \\
\end{array}$ & РСВ & $\begin{array}{l}\text { Chlorine } \\
\text { position }\end{array}$ & $\begin{array}{c}{ }^{1} \mathrm{D} \\
\text { Retention } \\
\text { Time (min) }\end{array}$ & $\begin{array}{c}{ }^{2} \mathrm{D} \\
\text { Retention } \\
\text { Time (s) } \\
\end{array}$ \\
\hline 54 & $26-2^{\prime} 6^{\prime}$ & 57.85 & 2.3 & 165 & $2356-3^{\prime} 5^{\prime}$ & 98 & 2.02 \\
\hline 50 & $246-2^{\prime}$ & 60.1 & 2.06 & 146 & $235-2^{\prime} 4^{\prime} 5^{\prime}$ & 98.3 & 2.08 \\
\hline 53 & $25-2^{\prime} 6^{\prime}$ & 62.3 & 2.15 & 161 & $2346-3^{\prime} 5^{\prime}$ & 98.75 & 2.04 \\
\hline 51 & $24-2^{\prime} 6^{\prime}$ & 63.45 & 2.15 & 168 & $246-3^{\prime} 4^{\prime} 5^{\prime}$ & 99.35 & 2.12 \\
\hline 45 & 236-2' & 65.05 & 2.22 & $153^{+}$ & $245-2^{\prime} 4^{\prime} 5^{\prime}$ & 99.55 & 2.1 \\
\hline 46 & 23-2'6' & 66.1 & 2.3 & 132 & 234-2'3'6' & 100 & 2.4 \\
\hline 73 & $26-3^{\prime} 5^{\prime}$ & 66.35 & 2.03 & 141 & $2345-25^{\prime}$ & 101.8 & 2.18 \\
\hline 69 & $246-3^{\prime}$ & 67.15 & 1.98 & 137 & $2345-2^{\prime} 4^{\prime}$ & 102.9 & 2.24 \\
\hline 43 & 235-2' & 67.35 & 2.09 & 130 & $234-2^{\prime} 3^{\prime} 5^{\prime}$ & 103.8 & 2.24 \\
\hline $52^{+}$ & 25-2'5' & 67.9 & 2 & 164 & $236-3^{\prime} 4^{\prime} 5^{\prime}$ & 103.95 & 2.25 \\
\hline 48 & $245-2^{\prime}$ & 68.25 & 2.1 & $138^{+}$ & 234-2'4'5' & 104.9 & 2.26 \\
\hline 49 & 24-2'5' & 68.75 & 2.02 & 160 & $23456-3^{\prime}$ & 105.15 & 2.22 \\
\hline 47 & 24-2'4' & 69.55 & 2.02 & 163 & $2356-3^{\prime} 4^{\prime}$ & 105.2 & 2.2 \\
\hline 65 & 2356 & 69.55 & 2.08 & 129 & $2345-2^{\prime} 3^{\prime}$ & 105.35 & 2.37 \\
\hline 62 & 2346 & 69.65 & 2.08 & 158 & $2346-3^{\prime} 4^{\prime}$ & 105.75 & 2.22 \\
\hline 75 & $246-4^{\prime}$ & 69.85 & 1.99 & 166 & $23456-4^{\prime}$ & 108.25 & 2.28 \\
\hline 44 & 23-2'5' & 71.4 & 2.16 & 159 & $2345-3^{\prime} 5^{\prime}$ & 109.25 & 2.02 \\
\hline 59 & 236-3' & 72.05 & 2.12 & 162 & $235-3^{\prime} 4^{\prime} 5^{\prime}$ & 110.2 & 2.06 \\
\hline 42 & $23-2^{\prime} 4^{\prime}$ & 72.25 & 2.17 & 128 & $234-2^{\prime} 3^{\prime} 4^{\prime}$ & 110.3 & 2.43 \\
\hline 71 & $26-3^{\prime} 4^{\prime}$ & 72.95 & 2.19 & $167^{*}$ & $245-3^{\prime} 4^{\prime} 5^{\prime}$ & 111.45 & 2.08 \\
\hline 41 & $234-2^{\prime}$ & 73.5 & 2.25 & $156^{*}$ & $2345-3^{\prime} 4^{\prime}$ & 115.75 & 2.22 \\
\hline $72^{*}$ & $25-3^{\prime} 5^{\prime}$ & 74.2 & 1.87 & $157^{*}$ & $234-3^{\prime} 4^{\prime} 5^{\prime}$ & 116.4 & 2.27 \\
\hline 64 & $236-4^{\prime}$ & 74.85 & 2.14 & $169^{*}$ & $345-3^{\prime} 4^{\prime} 5^{\prime}$ & 124 & 2.09 \\
\hline 68 & $24-3^{\prime} 5^{\prime}$ & 75 & 1.91 & \multicolumn{4}{|c|}{ Hepta-chlorobiphenyls } \\
\hline 40 & $23-2^{\prime} 3^{\prime}$ & 75.05 & 2.32 & 188 & $2356-2^{\prime} 4^{\prime} 6^{\prime}$ & 96.3 & 2.24 \\
\hline 57 & $235-3^{\prime}$ & 76.5 & 1.97 & 184 & $2346-2^{\prime} 4^{\prime} 6^{\prime}$ & 97.65 & 2.25 \\
\hline 58 & $23-3^{\prime} 5^{\prime}$ & 77.4 & 2.04 & 179 & $2356-2^{\prime} 3^{\prime} 6^{\prime}$ & 100.8 & 2.36 \\
\hline 67 & $245-3^{\prime}$ & 77.4 & 1.99 & 176 & $2346-2^{\prime} 3^{\prime} 6^{\prime}$ & 102.2 & 2.38 \\
\hline 61 & 2345 & 78.2 & 2.12 & 186 & $23456-2^{\prime} 6^{\prime}$ & 102.95 & 2.47 \\
\hline 76 & $345-2^{\prime}$ & 78.75 & 2.13 & 178 & $2356-2^{\prime} 3^{\prime} 5^{\prime}$ & 104.85 & 2.18 \\
\hline 63 & $235-4^{\prime}$ & 79.1 & 2.01 & 182 & $2345-2^{\prime} 4^{\prime} 6^{\prime}$ & 105.9 & 2.25 \\
\hline 74 & $245-4^{\prime}$ & 79.9 & 2.01 & 175 & $2346-2^{\prime} 3^{\prime} 5^{\prime}$ & 105.95 & 2.21 \\
\hline 70 & 25-3'4' & 80.4 & 2.03 & 187 & $2356-2^{\prime} 4^{\prime} 5^{\prime}$ & 106.45 & 2.22 \\
\hline 66 & 24-3'4' & 81.15 & 2.06 & 183 & $2346-2^{\prime} 4^{\prime} 5^{\prime}$ & 107.5 & 2.24 \\
\hline 80 & $35-3^{\prime} 5^{\prime}$ & 82.15 & 1.77 & 185 & $23456-2^{\prime} 5^{\prime}$ & 109.8 & 2.27 \\
\hline 55 & $234-3^{\prime}$ & 82.35 & 2.13 & 174 & $2345-2^{\prime} 3^{\prime} 6^{\prime}$ & 110.45 & 2.38 \\
\hline 56 & 23-3'4' & 83.65 & 2.2 & 181 & $23456-2^{\prime} 4^{\prime}$ & 111.45 & 2.34 \\
\hline 60 & $234-4^{\prime}$ & 84.85 & 2.16 & 177 & $2356-2^{\prime} 3^{\prime} 4^{\prime}$ & 112.4 & 2.38 \\
\hline 79 & $34-3^{\prime} 5^{\prime}$ & 88.2 & 1.92 & 171 & $2346-2^{\prime} 3^{\prime} 4^{\prime}$ & 113.25 & 2.4 \\
\hline 78 & $345-3^{\prime}$ & 89.4 & 2.01 & 173 & 23456-2'3' & 113.7 & 2.46 \\
\hline $81^{*}$ & $345-4^{\prime}$ & 92.1 & 2.05 & 172 & $2345-2^{\prime} 3^{\prime} 5^{\prime}$ & 115.3 & 2.22 \\
\hline 77 & $34-3^{\prime} 4^{\prime}$ & 94.2 & 2.08 & 192 & $23456-3^{\prime} 5^{\prime}$ & 115.85 & 2.12 \\
\hline \multicolumn{4}{|c|}{ Penta-chlorobiphenyls } & 180 & $2345-2^{\prime} 4^{\prime} 5^{\prime}$ & 116.7 & 2.22 \\
\hline 104 & $246-2^{\prime} 6^{\prime}$ & 69.2 & 2.21 & 193 & $2356-3^{\prime} 4^{\prime} 5^{\prime}$ & 117 & 2.21 \\
\hline 96 & $236-2^{\prime} 6^{\prime}$ & 73.9 & 2.36 & 191 & $2346-3^{\prime} 4^{\prime} 5^{\prime}$ & 117.85 & 2.24 \\
\hline 103 & $246-2^{\prime} 5^{\prime}$ & 74.55 & 2.06 & 170 & $2345-2^{\prime} 3^{\prime} 4^{\prime}$ & 122.05 & 2.42 \\
\hline 100 & $246-2^{\prime} 4^{\prime}$ & 75.9 & 2.06 & 190 & $23456-3^{\prime} 4^{\prime}$ & 122.95 & 2.33 \\
\hline 94 & $235-2^{\prime} 6^{\prime}$ & 76.15 & 2.2 & $189^{*}$ & $2345-3^{\prime} 4^{\prime} 5^{\prime}$ & 128.9 & 2.21 \\
\hline 102 & $245-2^{\prime} 6^{\prime}$ & 77.5 & 2.22 & \multicolumn{4}{|c|}{ Octa-chlorobiphenyls } \\
\hline 98 & $246-2^{\prime} 3^{\prime}$ & 78.4 & 2.2 & 202 & $2356-2^{\prime} 3^{\prime} 5^{\prime} 6^{\prime}$ & 111.2 & 2.32 \\
\hline 93 & $2356-2^{\prime}$ & 78.7 & 2.23 & 201 & $2346-2^{\prime} 3^{\prime} 5^{\prime} 6^{\prime}$ & 112.7 & 2.36 \\
\hline 88 & $2346-2^{\prime}$ & 79.3 & 2.23 & 204 & $23456-2^{\prime} 4^{\prime} 6^{\prime}$ & 112.7 & 2.36 \\
\hline 95 & $236-2^{\prime} 5^{\prime}$ & 79.35 & 2.2 & 197 & $2346-2^{\prime} 3^{\prime} 4^{\prime} 6^{\prime}$ & 114.15 & 2.39 \\
\hline 121 & $246-3^{\prime} 5^{\prime}$ & 79.45 & 1.93 & 200 & $23456-2^{\prime} 3^{\prime} 6^{\prime}$ & 117.1 & 2.49 \\
\hline 91 & $236-2^{\prime} 4^{\prime}$ & 80.8 & 2.21 & 198 & $23456-2^{\prime} 3^{\prime} 5^{\prime}$ & 121.6 & 2.29 \\
\hline 92 & $235-2^{\prime} 5^{\prime}$ & 82.8 & 2.04 & 199 & $2345-23^{\prime} 5^{\prime} 6$ ' & 121.85 & 2.34 \\
\hline 89 & $234-2^{\prime} 6^{\prime}$ & 83.25 & 2.36 & 196 & $2345-23^{\prime} 4^{\prime} 6^{\prime}$ & 123.05 & 2.37 \\
\hline 84 & $236-2^{\prime} 3^{\prime}$ & 83.35 & 2.34 & 203 & $23456-2^{\prime} 4^{\prime} 5^{\prime}$ & 123.3 & 2.33 \\
\hline
\end{tabular}




\begin{tabular}{|c|c|c|c|c|c|c|c|}
\hline РСB & $\begin{array}{l}\text { Chlorine } \\
\text { position }\end{array}$ & $\begin{array}{c}{ }^{1} \mathrm{D} \\
\text { Retention } \\
\text { Time (min) }\end{array}$ & $\begin{array}{c}{ }^{2} \mathrm{D} \\
\text { Retention } \\
\text { Time (s) }\end{array}$ & РСВ & $\begin{array}{l}\text { Chlorine } \\
\text { position }\end{array}$ & $\begin{array}{c}{ }^{1} \mathrm{D} \\
\text { Retention } \\
\text { Time (min) }\end{array}$ & $\begin{array}{c}{ }^{2} \mathrm{D} \\
\text { Retention } \\
\text { Time (s) }\end{array}$ \\
\hline 90 & $235-2^{\prime} 4^{\prime}$ & 83.9 & 2.08 & 195 & $23456-2^{\prime} 3^{\prime} 4^{\prime}$ & 129.05 & 2.52 \\
\hline $101^{+}$ & $245-2^{\prime} 5^{\prime}$ & 83.95 & 2.05 & 194 & $2345-2^{\prime} 3^{\prime} 4^{\prime} 5^{\prime}$ & 132.9 & 2.36 \\
\hline 113 & $236-3^{\prime} 5^{\prime}$ & 84.2 & 2.05 & 205 & $23456-3^{\prime} 4^{\prime} 5^{\prime}$ & 134.15 & 2.33 \\
\hline 99 & 245-2'4' & 84.9 & 2.1 & \multicolumn{4}{|c|}{ Nona-chlorobiphenyls } \\
\hline 119 & $246-3^{\prime} 4^{\prime}$ & 86.3 & 2.09 & 208 & $23456-2^{\prime} 3^{\prime} 5^{\prime} 6^{\prime}$ & 126.8 & 2.46 \\
\hline 83 & $235-2^{\prime} 3^{\prime}$ & 86.45 & 2.2 & 207 & $23456-23^{\prime} 4^{\prime} 6^{\prime}$ & 128.4 & 2.49 \\
\hline 125 & $345-2^{\prime} 6^{\prime}$ & 86.6 & 2.24 & 206 & $23456-2^{\prime} 3^{\prime} 4^{\prime} 5^{\prime}$ & 137.95 & 2.47 \\
\hline 112 & $2356-3^{\prime}$ & 86.7 & 2.09 & \multicolumn{4}{|c|}{ Deca-chlorobiphenyls } \\
\hline 86 & $2345-2^{\prime}$ & 86.8 & 2.27 & 209 & $234 \overline{456-2^{\prime} 3^{\prime} 4^{\prime} 5^{\prime} 6^{\prime}}$ & 141.85 & 2.6 \\
\hline
\end{tabular}

Table 2. Comparison of co-eluting congeners in different column combinations

\begin{tabular}{|c|c|c|c|c|}
\hline & $\begin{array}{l}\text { Megson et al. } 2013 \\
\text { (this study) }\end{array}$ & Harju et al. 2003 & Focant et al. 2004 & Zapadlo et al. 2011 \\
\hline Column set up & $\begin{array}{l}{ }^{1} \mathrm{D}-60 \mathrm{~m} \text { Rtx-PCB } \\
{ }^{2} \mathrm{D}-1.5 \mathrm{~m} \text { Rxi-17 }\end{array}$ & $\begin{array}{l}{ }^{1} \mathrm{D}-60 \mathrm{~m} \text { DB-XLB } \\
{ }^{2} \mathrm{D}-2.25 \mathrm{~m} \text { BPX-70 }\end{array}$ & $\begin{array}{c}{ }^{1} \mathrm{D}-60 \mathrm{~m} \text { DB-XLB }{ }^{2} \mathrm{D}- \\
2.5 \mathrm{~m} \text { BPX-50 }\end{array}$ & $\begin{array}{c}{ }^{1} \mathrm{D}-30 \mathrm{~m} \text { SPB-Octyl } \\
{ }^{2} \mathrm{D} \text { - SLB-IL59 }\end{array}$ \\
\hline \multirow{10}{*}{ Co-elutions } & $\mathrm{CB} 4 / 10^{\mathrm{a}}$ & $\mathrm{CB} 47 / 62 / 65$ & CB $20 / 21 / 33$ & CB 12/13 \\
\hline & CB 20/21/30 & CB 42/59 & CB $66 / 155^{\mathrm{b}}$ & CB 62/75 \\
\hline & CB $65 / 62$ & CB $86 / 112$ & CB $77 / 144^{b}$ & CB 70/76 \\
\hline & CB $58 / 67^{\mathrm{a}}$ & CB 106/109 & CB 84/89 & CB 90/101/113 \\
\hline & CB $88 / 95^{\mathrm{a}}$ & CB 175/182 & CB 90/101 & CB 97/125 \\
\hline & $\mathrm{CB} 84 / 89^{\mathrm{a}}$ & & CB 107/123 & CB 153/168 \\
\hline & $\mathrm{CB} 90 / 101^{\mathrm{a}}$ & & CB 153/168 & \\
\hline & CB160/163 & & & \\
\hline & CB $175 / 182^{\mathrm{a}}$ & & & \\
\hline & CB 201/204 & & & \\
\hline $\begin{array}{l}\text { Total number of } \\
\text { PCBs resolved }\end{array}$ & $188 / 209$ & $198 / 209$ & $194 / 209$ & 196/209 \\
\hline
\end{tabular}

\footnotetext{
a These congeners could be identified manually. However caution is advised when undertaking quantitative analysis.

${ }^{\mathrm{b}}$ Co-elution between tetra-CB and Hexa-CB $-2 \mathrm{Cl}$ fragment.
} 


\section{Figures}

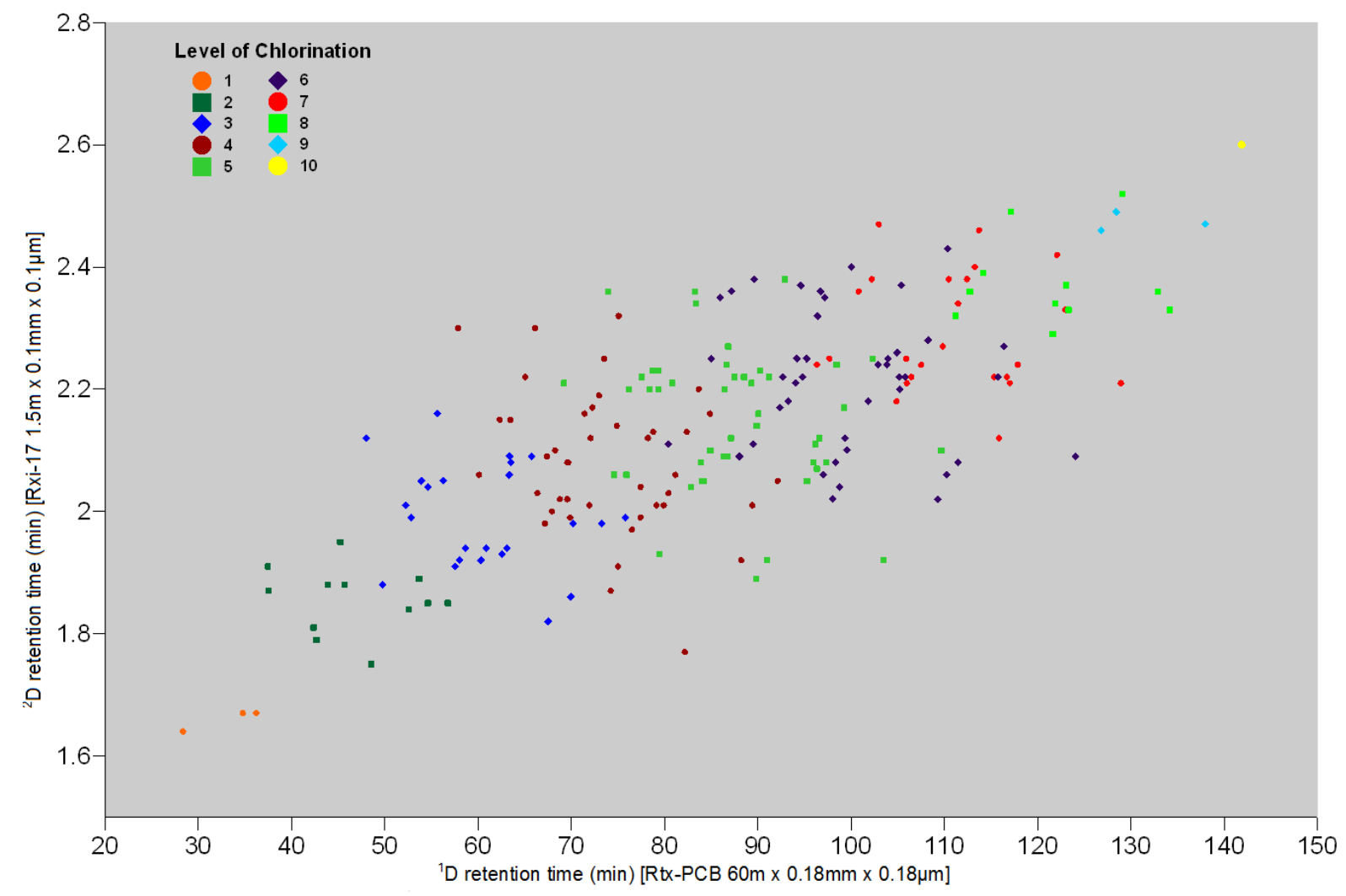

Figure 1. Plotted peak apexes representing the two-dimensional retention times for all 209 PCB congeners 

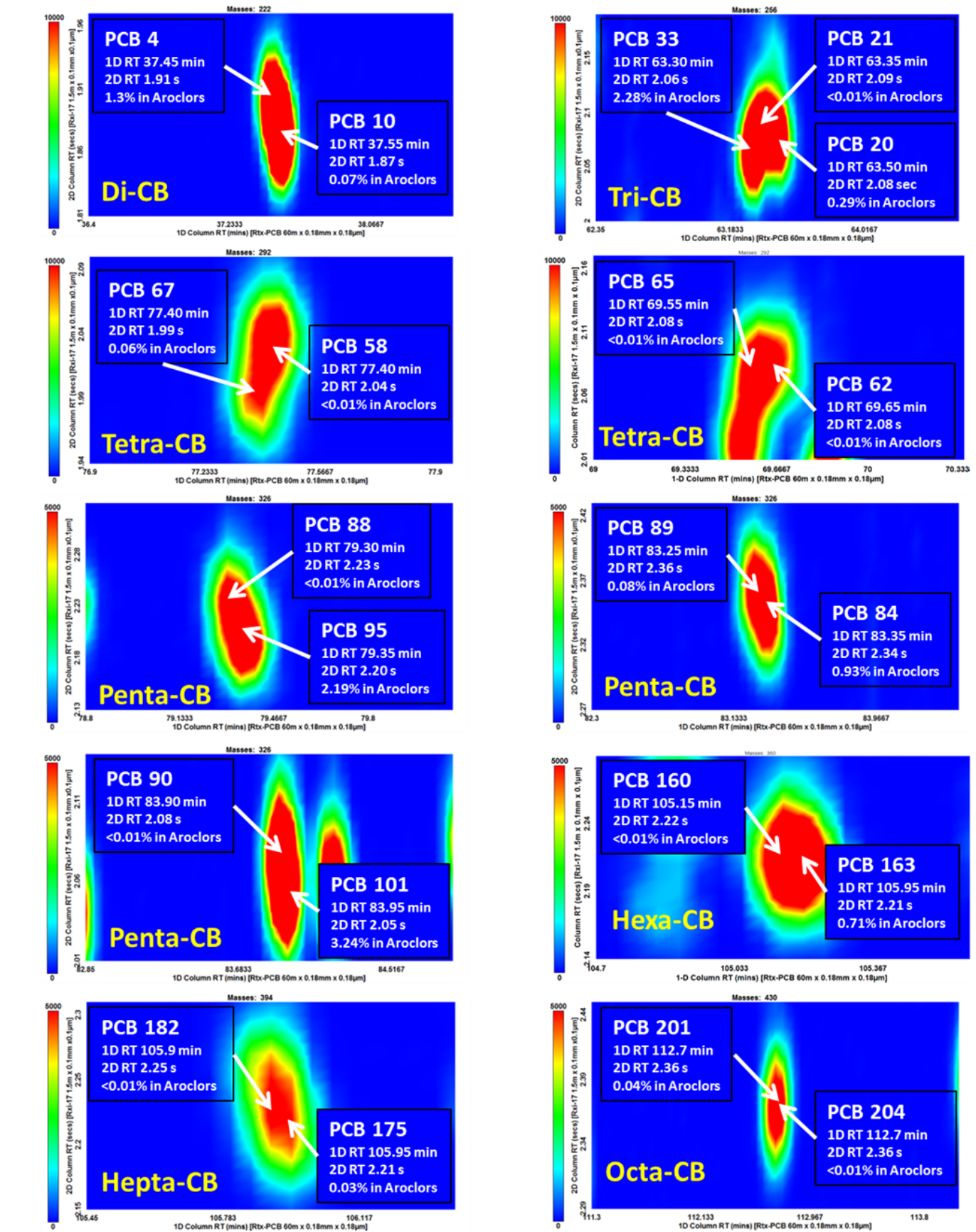

\begin{tabular}{|c|c|c|c|c|c|c|c|c|c|c|c|}
\hline & Mono-CB & DFCB & TH-CB & Tetra-CB & Penta-CB & Hexa-CB & Hepta-CB & Octa-CB & Nona-CB & Deca-CB & Total \\
\hline $\begin{array}{l}\text { Number of } \\
\text { Congreners }\end{array}$ & 3 & 12 & 24 & 42 & 46 & 42 & 24 & 12 & 3 & 1 & 209 \\
\hline $\begin{array}{l}\text { Peals Identifled } \\
\text { by GCxGC-TOFMS }\end{array}$ & 3 & 11 & 22 & 40 & 43 & 41 & 23 & 11 & 3 & 1 & 198 \\
\hline $\begin{array}{l}\text { Co-elutions of } \\
\text { PCB (B/Z } \\
\text { number) on } \\
\text { GOGC-TOFMS }\end{array}$ & none & $4^{3} / 10^{\circ}$ & $20 / 21 / 33$ & $\begin{array}{c}65 / 62 \\
67^{s} / 58^{s}\end{array}$ & $\begin{array}{c}88^{s} / 95^{5} \\
899 / 84^{9} \\
90^{5} / 101^{s}\end{array}$ & $160 / 163$ & $182^{s} / 175^{9}$ & $201 / 204$ & none & none & 10 \\
\hline
\end{tabular}

s Congeners separated by further data interpretation

Figure 2. Summary of congeners that could not be resolved by chromatography are presented as contour plots along with their documented retention times and percentage abundance in the five main Aroclors. 

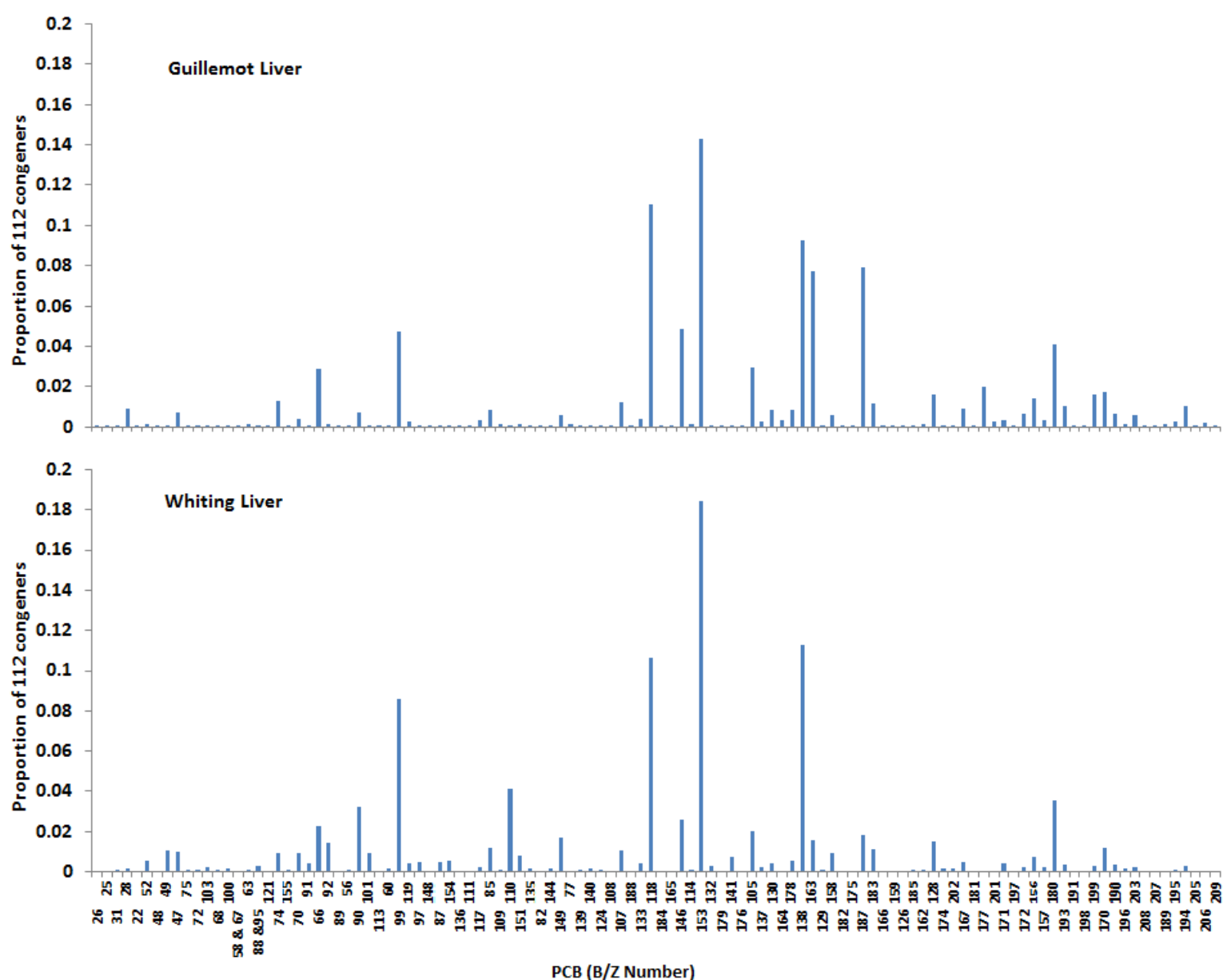

Figure 3. PCB signature in whiting and guillemot liver. One hundred and twelve PCBs were resolved by GCxGC-TOFMS in both samples. PCBs are arranged by elution order on the first dimension column (Rtx-PCB $60 \mathrm{~m}$ x $0.18 \mathrm{~mm}$ x $0.18 \mu \mathrm{m}$ ). 